\title{
KERAGAAN USAHATANI VARIETAS UNGGUL BARU (VUB) PADI SAWAH DENGAN POLA PENGELOLAAN TANAMAN TERPADU (PTT):Studi Kasus di Desa Aneuk Glee Kecamatan Indrapuri Nanggroe Aceh Darussalam
}

\section{(The Farm Performance of New Varieties of Sawah Paddy with Integrated Crop Management Pattern: Case study in Aneuk Glee Village subdistrict of Indrapuri Nanggroe Aceh Darussalam)}

\section{Emlan Fauzi ${ }^{1}$ dan Apri Andani ${ }^{2}$}

\section{Balai Pengkajian Teknologi Pertanian Nanggroe Aceh Darussalam}

2. Jurusan Sosial Ekonomi Pertanian Fakultas Pertanian Universitas Bengkulu

\begin{abstract}
This research aims to determine the performance of new varieties of farm (VUB), lowland rice through an integrated approach to crop management (ICM) in the village of Gle Aneuk Indrapuri, Aceh Besar District. Field assessment is from cooperative farmers who have lowland rice varieties with treatment, such as Cimelati, Bondoyudo, Ciherang, Kalimas, VUTB Fatmawati and IR-64. In each of these rice varieties applied packages introduced PTT technology. The result indicates that reviewed the six varieties suitable for cultivated and developed. Judging from the performance of agronomic VUTB Fatmawati better compared with 5 other varieties. VUTB Fatmawati have the greatest production (7.75 tonnes / ha) with a profit-making Rp.6.074.750, -. Fatmawati lowland rice farming system with ICM pattern is more feasible to be developed because the RC has the largest ratio (2.09) compared with the varieties Cimelati $(2,06)$, Kalimas $(2,04)$, Bondoyudo (2,02), Ciherang (1,51) and varieties of IR-164 (1,39).
\end{abstract}

Key words: farming, rice, varieties, integrated crop management

\section{PENDAHULUAN}

Pengelolaan Tanaman Terpadu (PTT) adalah tindakan usahatani secara terpadu yang bertujuan untuk memperoleh pertumbuhan tanaman optimal, kepastian panen, mutu produk tinggi, dan kelestarian lingkungan (Sumarno $d k k$., 2000). Keterpaduan dalam PTT bukan hanya terbatas pada keterpaduan antara tanaman, sumberdaya produksi dan teknologi, namun melibatkan keterpaduan yang lebih luas, yaitu: (1) keterpaduan antarinstutusi, keterpaduan antardisiplin ilmu pengetahuan, dan (3) keterpaduan analisis dan interpretasi. Tujuan PTT adalah meningkatkan produktivitas, meningkatkan nilai ekonomi usahatani malalui efisiensi input, dan melestarikan sumberdaya 
untuk keberlanjutan sistem produksi (Ferizal dkk, 2004). PTT bukan paket teknologi, tetapi suatu pendekatan agar sumber daya tanaman, lahan, dan air dikelola sebaik-baiknya untuk mencapai produktivitas lahan dan tanaman yang optimal. PTT berlandaskan pada hubungan sinergis antara dua atau lebih komponen teknologi produksi . Beberapa komponen teknologi seperti adaptasi varietas unggul baru, sistem tanam legowo, Intermitten Irigasi, bahan organik dan Bagan Warna Daun yang telah dihasilkan (Balitbangtan, 2002 dalam Ali Nasir, 2003). Pemupukan spesifik lokasi serta pengendalian hama dan penyakit merupakan komponen teknologi yang telah melewati tahap uji adaptasi di lahan petani (Ali Nasir, 2004).

Varietas unggul padi berperan besar dalam mengubah sistem pertanian subsistem menjadi usaha pertanian komersial karena kemampuan produksinya tiga kali lipat lebih tinggi dibanding varietas lokal. Pengembangan benih varietas unggul baru dirasakan mendesak untuk mengatasi stagnasi peningkatan produktivitas (leveling off) khususnya padi yang saat ini sudah makin dirasakan di sentra-sentra produksi. Ketersediaan varietas unggul di tingkat petani akan terus digalakkan dan dikembangkan dengan cara pemberdayaan kelompok-kelompok tani sebagai penangkar benih padi (Ali Nasir 2004). Peran penangkar benih padi dalam penyediaan benih bermutu sangat diperlukan untuk peningkatan produksi. Hal ini penting, karena benih dan varietas padi dapat mempengaruhi produktivitas. Varietas-varietas padi berumur genjah dan berproduksi hasil tinggi merupakan idaman bagi petani yang mengusahakan peningkatan frekwensi panen khususnya di daerah pengembangan tanaman padi.

Kabupaten Aceh Besar menjadi sentra produksi beras di Provinsi Aceh dan mempunyai areal sawah irigasi yang sangat memungkinkan dikembangkan teknologi budidaya padi model PTT. Introduksi varietas-varietas unggul baru dengan sifat-sifat genetik yang lebih baik diharapkan dapat meningkatkan kembali produktivitas tanaman. Diantara seluruh komponen teknologi, varietas merupakan teknologi yang paling mudah dan paling cepat diadopsi oleh petani.

Berangkat dari uraian di atas, maka pertanyaan yang perlu dijawab adalah bagaimana keragaan usahatani varietas unggul baru (VUB) padi sawah melalui pola pengelolaan tanaman terpadu (PTT) di Kecamatan Indrapuri Kabupeten Aceh Besar. Dengan demikian, tujuan dari penelitian ini adalah untuk mengetahui keragaan usahatani varietas unggul baru (VUB) padi sawah melalui pola pengelolaan tanaman terpadu (PTT) di Kecamatan Indrapuri Kabupeten Aceh Besar. 


\section{METODE PENELITIAN}

Penentuan lokasi pengkajian dilakukan secara sengaja (purposive) yaitu di Desa Aneuk Glee Kecamatan Indrapuri Kabupaten Aceh Besar Propinsi Aceh. Pengkajian dilakukan pada lahan sawah irigasi seluas 6 ha (enam hektar), yang melibatkan 10 orang petani kooperator yang berada pada satu hamparan. Pengkajian dilaksanakan dengan pendekatan On Farm Adaptive Research, mulai dari Januari sampai April 2008. Pengkajian lapangan di lahan sawah petani kooperator dengan perlakuan VUB padi sawah varietas Cimelati, Bondoyudo, Ciherang, Kalimas, VUTB Fatmawati dan IR-64. Pada masingmasing VUB padi tersebut diterapkan paket teknologi introduksi PTT. Beberapa komponen teknologi yang diimplementasikan pada unit hamparan pengkajian (UHP) seluas 6 ha meliputi; (a) penggunaan varietas unggul adaptif dan benih berkualitas, (b) perlakuan benih, (c) tanam tunggal bibit muda (15 hari setelah tebar), (d) penggunaan bahan organik (kompos), (e) pemupukan $\mathrm{N}$ berdasarkan Bagan Warna Daun, (f) pemupukan P dan $\mathrm{K}$ berdasarkan status hara tanah melalui uji tanah, (g) pengairan berselang (intermitten irigation), (h) pengendalian gulma dengan landak/gosrok), dan (i) pengendalian hama secara PHT, untuk lebih lengkap dapat dilihat lampiran1.

\section{Analisis Data}

a. Data Pengkajian Lapang ditabulasi dan dianalisa secara deskriptif yang meliputi komponen hasil (jumlah malai per rumpun, panjang malai dan gabah bernas permalai)

b. Data Analisa Usahatani,

Analisa usahatani pada masing-masing varietas padi sawah tersebut, meliputi :

- Analisa Produktivitas

Produktivitas dapat dihitung berdasarkan hasil persatuan luas lahan

Produktivitas $=\frac{\text { Produksi }}{\text { Luas Lahan }}$

- Analisa Pendapatan

Analisa pendapatan dapat dihitung melalui rumus : $\mathrm{Pd}=\mathrm{TR}-\mathrm{TC}$ (Syafiri M, 2004).

Keterangan $: \mathrm{Pd}=$ Pendapatan; TR= Total Penerimaan; $\mathrm{TC}=$ Total Biaya

- Kelayakan Usahatani 
Analisis kelayakan usahatani dihitung berdasarkan rumus :

RC = TR/TC (Nurmanaf,et al, 2005 dalam Ariani, M dkk 2009)

Dimana:

$\mathrm{R} / \mathrm{C}=$ Nisbah penerimaan dan biaya

$\mathrm{TR}=$ Total Penerimaan $(\mathrm{Rp} / \mathrm{ha})$

$\mathrm{TC}=$ Total Biaya $(\mathrm{Rp} / \mathrm{ha})$

Dengan Kriteria :

$\mathrm{R} / \mathrm{C}>1$, usahatani secara ekonomi menguntungkan

$\mathrm{R} / \mathrm{C}=1$, usahatani secara ekonomi berada pada titik impas (BEP)

$\mathrm{R} / \mathrm{C}<1$, usahatani secara ekonomi tidak menguntungkan (rugi)

\section{HASIL DAN PEMBAHASAN}

\section{Keragaan Tanaman VUB Padi Sawah dengan Pola PTT}

Hasil pengukuran jumlah malai/rumpun terbanyak terdapat pada varietas Bondoyudo (15,4 malai/rumpun) diikuti varietas cimelati $(14,8$ malai/rumpun), kalimas (14,2 malai/rumpun), Fatmawati (12,0 malai/rumpun) dan varietas IR-64 (12 malai/rumpun). Hal ini diduga dipengaruhi oleh munculnya anakan baru pada fase generatif (Chairunas dkk, 2004). Semakin banyak jumlah malai per rumpun tidak selalu berkorelasi dengan jumlah gabah yang dihasilkan. Varietas Bondoyudo mempunyai jumlah malai terbanyak $(15,4$ malai/rumpun) namun jumlah gabah yang dihasilkan masih rendah dibandingkan dengan varietas fatmawati.

Tabel 2 menunjukkan bahwa malai rata-rata terpanjang terdapat pada varietas fatmawati $(30,2 \mathrm{~cm})$ dan malai terpendek terdapat pada varietas IR-64 $(22.0 \mathrm{~cm})$. Dilihat dari panjang malai yang dihasilkan diduga dipengaruhi oleh faktor genetik tanaman padi (Puslitbangtan, 2002), selain hal tersebut ketersediaan air pada lahan dapat juga memperpanjang malai padi (Chairunas dkk, 2004).

Hasil perhitungan gabah per malai menunjukkan gabah terbanyak terdapat pada varietas fatmawati (292,0 butir), diikuti oleh varietas bondoyudo (124.0 butir), kalimas (120,1 butir), ciherang (101,8 butir), cimelati $(101,8)$ dan terendah pada varietas IR-64 (98,3 butir). Semakin panjang malai ternyata berkorelasi dengan jumlah gabah yang dihasilkan oleh malai tersebut. VUTB Fatmawati mempunyai malai terpanjang dan gabah yang muncul ditiap malai paling banyak. Jumlah gabah dipengaruhi oleh pasokan hasil fotosintesis dan 
kemampuan tanaman untuk menyerap unsur hara yang diperlukan pada saat pembentukan malai dan buah (Chairunas dkk, 2004). Selain itu sifat genetik varietas juga sangat mempengaruhi jumlah gabah per malai (Puslitbangtan, 2002).

Tabel 2. Rata-rata Jumlah Malai, Panjang Malai dan Jumlah Gabah Permalai Masing-masing Varietas

\begin{tabular}{clccc}
\hline No & \multicolumn{1}{c}{ Varietas } & $\begin{array}{c}\text { Malai/ } \\
\text { Rumpun }\end{array}$ & $\begin{array}{c}\text { Panjang Malai } \\
(\mathbf{C m})\end{array}$ & $\begin{array}{c}\text { Jumlah Gabah Isi } \\
\text { Per Malai }\end{array}$ \\
\hline 1. & Cimelati & 14.8 & 23.80 & 101,8 \\
2. & Bondoyudo & 15.4 & 24,50 & 124,0 \\
3. & Ciherang & 14.0 & 24,00 & 110,8 \\
4. & Kalimas & 14,0 & 24,12 & 120,1 \\
5. & Fatmawati & 12,0 & 30,20 & 292,0 \\
6. & IR-64 & 12,0 & 22.00 & 98,3 \\
\hline
\end{tabular}

\section{Analisa Usahatani VUB Padi Sawah dengan Pola PTT}

Suatu usahatani dikatakan berhasil apabila memperoleh keuntungan dengan korbanan biaya produksi yang efisien (Syafiri M, 2004). Efisiensi ekonomi diperoleh apabila secara produksi usahatani mencapai hasil optimal dan dapat mendistribusikan produknya ke konsumen dengan harga yang layak. Analisis usahatani dilakukan berdasarkan biaya produksi yang dikeluarkan dan hasil produksi yang diperoleh. Adapun yang termasuk biaya produksi adalah biaya sarana produksi (alat dan bahan yang digunakan) dan biaya tenaga kerja yang dipakai pada usahatani. Sedangkan produksi adalah hasil yang diperoleh dari usahatani baik berupa natura atau uang.

\section{Produktivitas}

Tinggi rendahnya produksi pertanian ditentukan oleh tingkat penerapan teknologi pertanian. Salah satu indikatornya adalah penggunaan sarana produksi seperti penggunaan pupuk, benih, pestisida dan tenaga kerja. Produksi pertanian disini terdiri dari jumlah padi sawah yang dihasilkan oleh petani dalam satu kali musim tanam.

Berdasarkan Tabel 3 menunjukkan bahwa produktivitas tertinggi terdapat pada VUTB Fatmawati (7.75 ton/ha), diikuti oleh varietas cimelati $(7,6$ ton/ha), varietas kalimas (7,5 ton/ha), varietas Bondoyudo (7,4 ton/ha), 
ciherang (5,3 ton/Ha) dan terendah terdapat pada IR-64 (4,8 ton/ha). Hal ini menunjukkan bahwa varietas Fatmawati lebih adaptif dibandingkan dengan varietas unggul lainnya. Secara ekonomis, apabila biaya produksi dan harga jual diasumsikan sama maka produksi yang paling tinggi akan menguntungkan petani. Dari perhitungan produksi maka varietas yang menguntungkan adalah VUTB Fatmawati.

Tabel 3. Hasil Analisis Usahatani Masing-Masing Varietas.

\begin{tabular}{|c|c|c|c|c|c|c|}
\hline \multirow[b]{2}{*}{ Jenis Kegiatan } & \multicolumn{6}{|c|}{ Varietas } \\
\hline & Cimelati & $\begin{array}{c}\text { Bondo- } \\
\text { Yudo }\end{array}$ & $\begin{array}{l}\text { Cihe- } \\
\text { rang }\end{array}$ & Kalimas & $\begin{array}{c}\text { Fatma- } \\
\text { wati }\end{array}$ & IR-64 \\
\hline $\begin{array}{l}\text { Produksi } \\
\text { (ton/ha) }\end{array}$ & 7,60 & 7,40 & 5,30 & 7,50 & 7,75 & 4 \\
\hline $\begin{array}{l}\text { Biaya Produksi } \\
\text { a. Benih }(\mathrm{Rp} / \mathrm{Kg}) \\
\text { b. Pupuk }(\mathrm{Rp} / \mathrm{Kg})\end{array}$ & 0 & 00 & 0 & 00 & 7.500 & 87.500 \\
\hline - Ure & 450.000 & 450.000 & 450.000 & 450.000 & 450.000 & 450.000 \\
\hline - SP-36 & 00 & 390.000 & 390.000 & 0.000 & 390.000 & 390.000 \\
\hline$-\mathrm{KC}$ & & 350.0 & 350.000 & 0.000 & 350.000 & 350.000 \\
\hline $\begin{array}{ll}- & \mathrm{P} . \\
& \mathrm{Kal}\end{array}$ & .000 & 550.000 & 550.000 & 550.000 & 550.000 & 550.000 \\
\hline $\begin{array}{l}\text { c. Pestisida } \\
\text { Rp/ha) }\end{array}$ & 3.750 & 38.750 & 38.750 & 38.750 & 38.750 & 38.750 \\
\hline d. Tenaga Kerj & 2.634 .000 & 2.634 .000 & 2.634 .000 & 2.634 .000 & 2.634 .000 & 2.634 .000 \\
\hline e. Pasca & 1.032 .000 & 1.008 .000 & 756.000 & 1.020 .000 & 1.050 .000 & 696.00 \\
\hline $\begin{array}{l}\text { Total Biaya } \\
\text { Produksi }\end{array}$ & 5.532 .250 & 5.508 .250 & 5.256 .250 & 5.520 .250 & 5.550 .250 & 5.196 .250 \\
\hline Penerimaan & 11.400 .000 & 11.100 .00 & 7.950 .000 & 11.250 .00 & 11.625 .00 & 7.200 .0 \\
\hline (Rp/ha) & & $\mathbf{0}$ & & $\mathbf{0}$ & 0 & \\
\hline $\begin{array}{l}\text { Pendapatan } \\
\text { (Rp/ha) }\end{array}$ & 750 & 5.591 .750 & 2.693 .750 & 5.739 .750 & 6.074 .750 & 003.7 \\
\hline $\mathrm{R} / \mathrm{C}$ & 2.06 & 2.02 & 1.51 & 2.04 & 2.09 & 1, \\
\hline
\end{tabular}

\section{Biaya Produksi}

Total biaya produksi usahatani merupakan penjumlahan dari biaya tetap dan biaya tidak tetap yang dikeluarkan oleh petani dalam satu kali musim tanam. Dari tabel 3 menunjukkan biaya usahatani yang paling besar terdapat 
pada VUTB Fatmawati (5.550.250) dan yang terkecil varietas IR 64 sebesar 5.196.250.

Terdapat perbedaan struktur biaya antar varietas, hal ini disebabkan terutama pada pengunaan biaya pasca panen. Dimana biaya yang dikeluarkan adalah untuk membayar sewa mesin perontok (power tresher). Besarnya biaya yang dikeluarkan tergantung dari hasil panen yang diperoleh, dengan sistem bagi hasil 10:1 (sepuluh karung padi yang telah dirontokkan satu karung untuk pemilik mesin). Dilihat dari tabel 3 VUTB Fatmawati lebih besar mengelaurkan biaya sewa mesin perontok karena produksi yang dihasilkan lebih tinggi dibandingkan dengan varietas lainnya.

\section{Penerimaan}

Penerimaan usahatani adalah perkalian antara produksi dengan harga jual produksi yang dihasilkan yaitu dalam bentuk Gabah Kering Panen dengan satuan kilogram $(\mathrm{Kg})$. Penerimaan dalam penelitian ini adalah pendapatan kotor yang diterima oleh petani dari hasil penjualan padi sawah dalam bentuk Gabah Kering Panen (GKP) yang dikalikan dengan harga. Di daerah penelitian harga gabah sebesar Rp. 1500/Kg dalam bentuk gabah kering panen. Atas dasar produksi dan harga tersebut, maka dapat dihitung penerimaan usahatani padi sawah.

Berdasarkan tabel 4 di atas menunjukkan bahwa penerimaan paling besar terdapat pada VUTB Fatmawati yaitu sebesar Rp. 11.625.000 dan yang terendah adalah varietas IR-64 (Rp. 7.200.000). Hal ini di sebabkan jumlah produksi yang dihasilkan oleh VUTB Fatmawati lebih tinggi dibandingkan dengan varietas yang lain. Besar kecilnya nilai penerimaan yang diterima oleh petani sangat ditentukan oleh besar kecilnya jumlah produksi yang dihasilkan dan harga yang diterima oleh petani.

\section{Pendapatan}

Pendapatan usahatani sangat ditentukan oleh penerimaan dari produksi yang dihasilkan dan biaya-biaya yang dikeluarkan. Pendapatan usahatani diperoleh dari selisih antara penerimaan total dengan biaya produksi total. Pendapatan usahatani ini sebenarnya merupakan balas jasa tanaman dari kerjasama faktor-faktor produksi yang digunakan (Fauzi E 2006). Pendapatan yang diukur adalah pendapatan yang diterima oleh petani dari hasil penjualan gabah padi dalam bentuk Gabah Kering Panen (GKP) setelah dikurangi biaya produksi. Hasil penelitian menunjukkan bahwa pendapatan tertinggi terdapat pada varietas Fatmawati (Rp. 6.074.750,-), disusul oleh varietas cimelati (Rp. 
5.867.750,-), kalimas (Rp. 5.729.750,-), bondoyudo (Rp. 5.591.750,-), ciherang (Rp.2.950.000,-) dan terendah pada varietas IR-64 (Rp.2.003.750,-).

\section{Kelayakan Usahatani}

Usahatani dianggap layak secara finansial maupun secara ekonomi jika nila revenue dan cost rationya (R/C) lebih dari satu (Ariani M, dkk 2009). Dari hasil analisis R/C ratio yang tertinggi diperoleh VUTB Fatmawati (2.09) disusul oleh cimelati (2.06), Kalimas (2.04), bondoyudo (2.02), ciherang (1.51) dan terendah varietas IR-164 (1.39). Dilihat dari R/C ratio menunjukkan bahwa masing-masing varietas secara ekonomis cukup layak dan menguntungkan untuk digunakan dalam usahatani padi sawah. Namun dari hasil analisis menunjukkan bahwa keuntungan dan efisiensi usahatani padi sawah menggunakan VUTB Fatmawati lebih besar dari pada varietas lainnya. Setiap penambahan biaya produksi menggunakan VUTB Fatmawati sebesar Rp.100 akan menambah keuntungan sebesar Rp. 209.

\section{KESIMPULAN}

Melalui pola PTT keenam varietas yang dikaji di Desa Aneuk Gle Kecamatan Indrapuri Kabupaten Aceh Besar layak untuk diusahakan dan dikembangkan. Dilihat dari keragaan agronomi VUTB Fatmawati lebih baik dibandingkan dengan 5 varietas lainnya. VUTB Fatmawati mempunyai produksi paling besar (7,75 ton/ha) dengan keuntungan sebesar Rp.6.074.750,-. Usahatani padi sawah varietas Fatmawati dengan pola PTT lebih layak untuk dikembangkan karena mempunyai RC ratio paling besar $(2,09)$ dibanding dengan varietas lainya.

\section{DAFTAR PUSTAKA}

Ali Nasir, 2004. Pengkajian Model Pengelolaan Tanaman Padi Terpadu di Lahan Sawah irigasi. Laporan Akhir Pengkajian BPTP NAD (unpublished).

Ali Nasir, Nur, M, Iskandar, T. 2003. Pengkajian Peningkatan Produktivitas padi Terpadu (P3T) dan Crop Livestock Sistem (CLS) di Kabupaten Aceh Barat. Laporan Akhir Pelaksanaan Kegiatan BPTP NAD dengan KPPKP Aceh Barat. Banda Aceh (unpublished)

Ferizal, M; Nur, M; Ali, N. 2004. Analisis Kebijakan Program Pengelolaan Tanaman dan Sumberdaya Terpadu di Provinsi NAD. Laporan Akhir Pengkajian BPTP NAD (unpublished).

Puslitbangtan. 2002. Deskripsi varietas unggul padi dan palawija 2000-2002. Pusat Penelitian dan Pengembangan Tanaman Pangan, Bogor. 
ISSN: $1412-8837$

Sumarno, I. G. Ismail, dan S. Partohardjono. 2000. Konsep usahatani ramah lingkungan. Dalam Prosiding Tonggak Kemajuan Teknologi Produksi Tanaman Pangan. Konsep dan Strategi Peningkatan Produksi Pangan. Pusat Penelitian dan Pengembangan Tanaman Pangan. Badan Litbang Pertanian. Hal. 55-74.

174 | Emlan Fauzi dan Apri Andani. Keragaan Usahatani Varietas Unggul Baru 